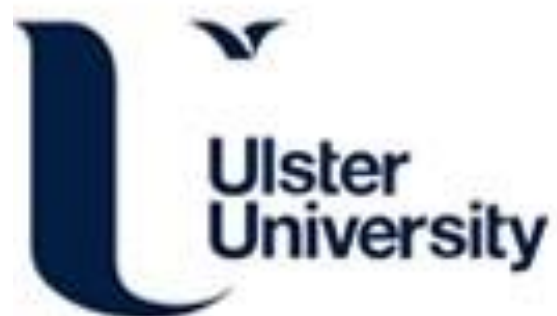

\section{The suitability of wood pellet heating for domestic households: A review of literature}

Thomson, H., \& Liddell, C. (2015). The suitability of wood pellet heating for domestic households: A review of literature. Renewable and Sustainable Energy Reviews, 42, 1362-1369.

Link to publication record in Ulster University Research Portal

\section{Published in:}

Renewable and Sustainable Energy Reviews

Publication Status:

Published (in print/issue): 01/01/2015

\section{Document Version}

Publisher's PDF, also known as Version of record

\section{General rights}

Copyright for the publications made accessible via Ulster University's Research Portal is retained by the author(s) and / or other copyright owners and it is a condition of accessing these publications that users recognise and abide by the legal requirements associated with these rights.

\section{Take down policy}

The Research Portal is Ulster University's institutional repository that provides access to Ulster's research outputs. Every effort has been made to ensure that content in the Research Portal does not infringe any person's rights, or applicable UK laws. If you discover content in the Research Portal that you believe breaches copyright or violates any law, please contact pure-support@ulster.ac.uk. 


\title{
The suitability of wood pellet heating for domestic households: A review of literature
}

\author{
Harriet Thomson ${ }^{\mathrm{a}, *}$, Christine Liddell $^{\mathrm{b}}$ \\ a The Department of Social Policy and Social Work, The University of York, Heslington, York, YO10 5DD, United Kingdom \\ ${ }^{\mathrm{b}}$ School of Psychology, University of Ulster, Cromore Road, Coleraine, Northern Ireland, BT52 1SA, United Kingdom
}

\section{A R T I C L E I N F O}

\section{Article history:}

Received 2 July 2014

Received in revised form

27 October 2014

Accepted 3 November 2014

Available online 19 November 2014

\section{Keywords:}

Wood pellet heating

Biomass

Pellet boiler

Low-income

Domestic heating

Renewable heating

\begin{abstract}
A B S T R A C T
Due to increasing government support for renewable energy in combination with high fossil fuel prices and environmental concerns, demand for wood pellet heating is rising all over Europe. Despite the rapid growth in wood pellet heating, the suitability and usability of wood pellet boilers in domestic settings has received relatively little attention compared with either alternative renewable heating technologies or with commercial applications of biomass heating. This article brings together the fragmented literature on wood pellet heating, and the application of this heating type in domestic settings, with a particular focus on assessing the suitability of wood pellet heating for low-income households who are not connected to the natural gas network.

The main advantages that have been identified include avoidance of significant levels of $\mathrm{CO}_{2}$ emissions, a potential reduction in heating costs, and increased comfort. However, it is clear that a number of potential risks exist at all stages of the supply chain, and that wood pellet heating has a heavy reliance on perfection of design and maintenance for optimal performance and safety, both in terms of pellets and boilers. Furthermore, the capital cost associated with wood pellet heating is found to be a key deterrent to uptake. It is acknowledged that - for some specific households who are able to accommodate the regular maintenance and manual labour associated with a wood pellet boiler domestic wood pellet heating can be a viable alternative to fossil fuel systems. At the present time, however, it is concluded that wood pellet boiler systems are not especially suited to application in domestic settings due to the range of end-user problems that can occur, concerns about pellet supply and pricing, and maintenance requirements. There is, however, considerable potential for wood pellet fuel to be utilised in district heating networks.
\end{abstract}

(c) 2014 Elsevier Ltd. All rights reserved.

\section{Contents}

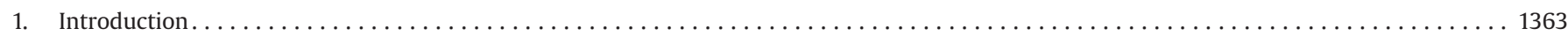

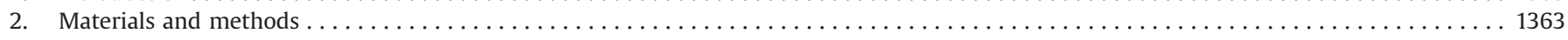

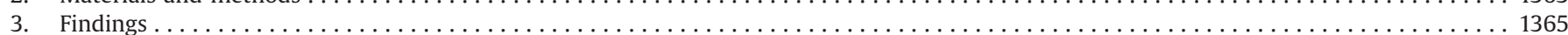

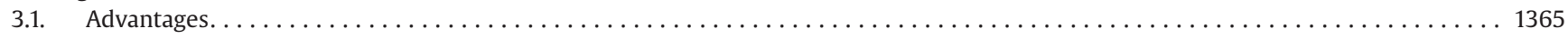

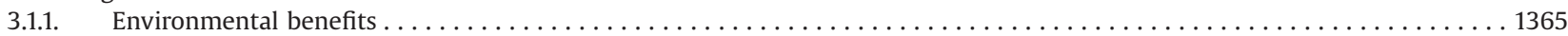

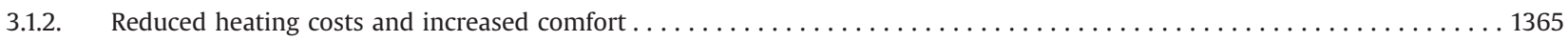

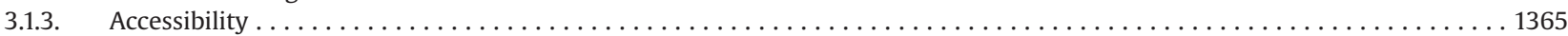

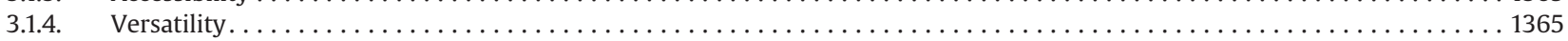

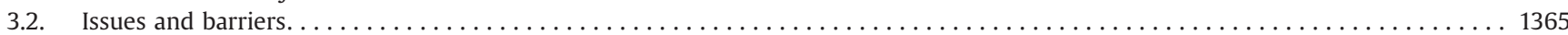

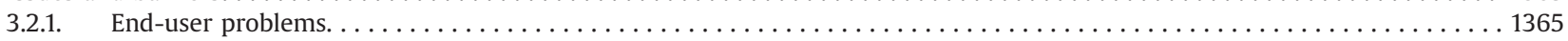

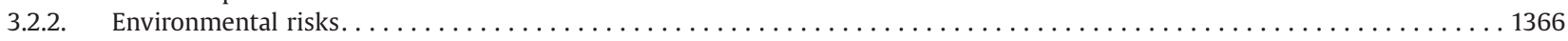

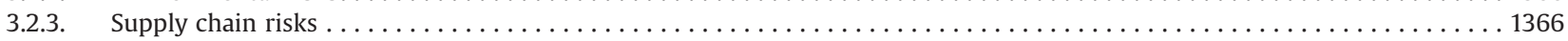

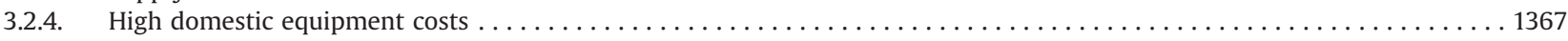

\footnotetext{
* Corresponding author. Tel.: +01904 321152.

E-mail addresses: hrt500@york.ac.uk (H. Thomson), C.Liddell@ulster.ac.uk (C. Liddell).
} 


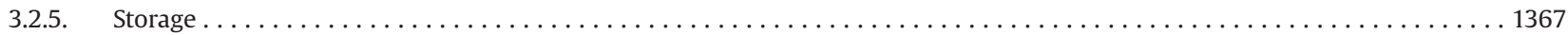

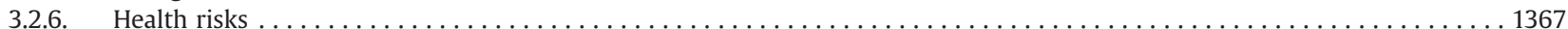

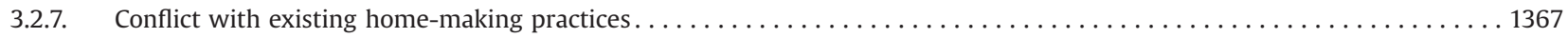

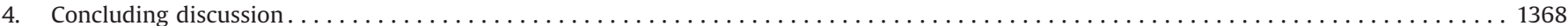

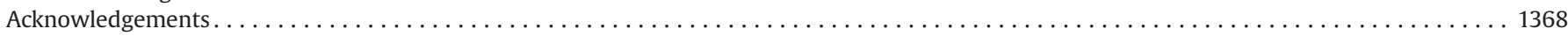

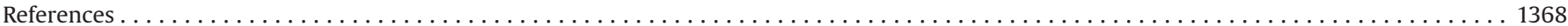

\section{Introduction}

Countries across Europe are obligated to take measures to increase their national share of renewable energy sources in order to meet the EU-wide target of $20 \%$ renewable energy usage by 2020, as laid out in the EU Directive 2009/28/EC concerning renewable energy [1]. Decreasing reliance on fossil fuels for domestic heating, in favour of renewable heating sources, is an area in which substantial gains can be made to meet national targets, whilst also helping to reduce the significant environmental damage caused by fossil fuel combustion, including acid rain and urban smog [2].

One area of renewable heating that shows early promise is biomass heating. Biomass is the general term given to any organic matter derived from plants, including wood from forests, and material left over from forestry processes [2]. Heating with wood is not a new concept for many households; most common is the burning of wood in log form in an open fire, often in conjunction with a back boiler to provide central heating and hot water [3]. However, open log fires are very inefficient, thus modern closed system heating appliances have been developed, which utilise a variety of forms of biomass, such as wood pellets, which are made from sawdust, shavings, bark or chips [3], and are produced by using high pressure and temperature to compress biomass wood material into small pellets that are cylindrical in shape [4].

As an alternative to oil, wood pellet systems have many advantages for low-income off-gas grid households. Aside from being a lower-carbon technology, they can be more affordable on a limited budget, and can be purchased in small quantities that limit the strain on low incomes. Householders can purchase several bags of pellets at any one time, at a cost approximating a single 201 drum of oil. Case studies from Northern Ireland indicate that wood pellet systems have customer appeal in many low-income households, and can halve heating bills of low-income households living in energy inefficient homes [5]. Although wood pellet markets first emerged in lumber-producing countries such as Sweden, Denmark, Austria and the United States [6], government support for renewable energy in combination with high fossil fuel prices has driven a demand for wood pellets all over Europe [4-8]. In 2012, EU27 countries consumed an estimated 15.1 million tonnes of wood pellets [9], with almost six million tonnes used for residential heating [9].

Despite the rapid growth in wood pellet heating, the suitability and usability of wood pellet heating in domestic settings has received relatively little attention compared with the three alternative renewable heating technologies, namely ground source heat pumps, air source heat pumps and solar thermal systems, or compared with commercial use of wood pellet heating. This article aims to address this gap in literature by combining the existing fragmented literature concerning wood pellets and wood pellet boilers, and assessing the opportunities and barriers associated with domestic wood pellet heating, with a specific focus on wood pellet boilers rather than stoves. Wood pellet boilers, and the distributed heating systems attached to them, offer wholehouse solutions to households, whilst stoves are more often used as an adjunct to central heating fired by other means.
Consequently wood pellet boilers are likely to be a more wideranging heating solution than are stoves.

The review is particularly interested in assessing the suitability of wood pellet heating for low-income households who are not connected to the natural gas network, where possible, as these households are likely to be the most vulnerable and least resilient to rising prices for more traditional sources of fossil fuel.

\section{Materials and methods}

This study is based on a narrative literature review, which was conducted in several phases in May 2014:

- A list of key terms relating to wood pellet heating and domestic households was drawn up $(n=15)$, as outlined in Table 1 .

- These 15 search terms were then entered into four electronic research databases (ScienceDirect, Web of Science, IngentaConnect and Zetoc), using various combinations and the Boolean operators 'AND' as well as 'OR'. The timespan used for the database searches was all years.

- Of the retrieved articles, approximately 50 relevant articles from the literature search were selected and assessed manually after scanning the title and abstract. Whilst sufficient to justify a narrative literature review, research and evaluation remain scarce when compared with studies concerned with either other renewables or wood pellet boiler systems in commercial sectors.

- The review was further supplemented with 'grey' sources of literature and information, obtained through general internet searches using the aforementioned search terms. Relevant resources, including newsletters and case studies, were downloaded and used in the narrative literature review. This latter step was taken as there is limited academic literature that specifically addresses the domestic use of wood pellet boilers.

In total, almost 40 articles were assessed and used in this narrative literature review. Table 2 summarises the main characteristics of the cited articles in terms of their methods, focus and country/countries of interest.

Given the broad geographic scope of the cited papers, and the variations in national definitions of poverty, we have chosen to use a basic conceptualisation of a 'low income household' as one that earns a low income (relative to national contexts).

Table 1

Review search terms.

\begin{tabular}{lll}
\hline - Willingness to pay & - Household & - Pellet boiler \\
- Attitudes & - Socioeconomic & $\bullet$ Wood pellet heating \\
- Adoption & - SES & $\bullet$ Biomass heating \\
- Uptake & - Renewable energy & $\bullet$ Wood fuel \\
- Domestic & $\bullet$ Wood pellet boiler & $\bullet$ Wood-based energy \\
\hline
\end{tabular}


Table 2

Summary of cited articles.

\begin{tabular}{|c|c|c|}
\hline Source & Country/countries studied & Methods and focus \\
\hline [1] Directive 2009/28/EC & European Union & Pan-EU policy document concerning renewable energy sources \\
\hline [2] Saidur et al., 2011 & Global & Review of burning biomass in boilers \\
\hline $\begin{array}{l}\text { [3] Sustainable Energy } \\
\text { Authority of Ireland, } 2012\end{array}$ & Ireland & Grey literature, expert consumer guide to biomass fuels and boilers \\
\hline [4] Karkania et al., 2012 & Greece & $\begin{array}{l}\text { A review of the agricultural residues pellets' market in Greece, based on published literature and official } \\
\text { market statistics }\end{array}$ \\
\hline [5] Liddell, 2011 & Northern Ireland & $\begin{array}{l}\text { Grey literature, an evaluation of a hard to treat housing project that installed energy efficiency and } \\
\text { renewable energy measures, including wood pellet boilers }\end{array}$ \\
\hline [6] Olsson et al., 2011 & $\begin{array}{l}\text { Austria, Germany and } \\
\text { Sweden }\end{array}$ & $\begin{array}{l}\text { Secondary analysis of time series wood pellet price data to determine whether the residential wood } \\
\text { pellet markets of Austria, Germany and Sweden are integrated }\end{array}$ \\
\hline [7] Sikkema et al., 2011 & Europe & A review of European wood pellet markets, based on published literature and official market statistics \\
\hline [8] Mola-Yudego et al., 2014 & Europe & Spatial analysis of the distribution of wood pellet production plants in Europe \\
\hline $\begin{array}{l}\text { [9] European Biomass } \\
\text { Association, } 2013\end{array}$ & Europe & $\begin{array}{l}\text { Grey literature, a review of biomass market trends and policy, based on secondary data analysis of } \\
\text { numerous datasets, and policy analysis }\end{array}$ \\
\hline [10] Sopha et al., 2011 & Norway & $\begin{array}{l}\text { A postal survey of adopters and non-adopters of wood pellet heating, to understand the differences } \\
\text { between the two groups }\end{array}$ \\
\hline [11] Lillemo et al., 2013 & Norway & $\begin{array}{l}\text { An online survey of households to determine how attitudes, motives, residence characteristics and } \\
\text { socioeconomic factors relate to households' investments in various types of heating equipment, } \\
\text { including pellet stoves }\end{array}$ \\
\hline $\begin{array}{l}\text { [12] Michelsen and Madlener, } \\
2012\end{array}$ & Germany & $\begin{array}{l}\text { A postal survey and discrete choice analysis of homeowners to establish the determinants of adopting } \\
\text { innovative heating systems }\end{array}$ \\
\hline [13] Sutherland Tables, 2014 & UK & Comparative heating costs data for various domestic fuels, including wood pellets \\
\hline $\begin{array}{l}\text { [14] Gray, Thomson and Liddell, } \\
2014\end{array}$ & Northern Ireland & $\begin{array}{l}\text { Feasibility study of wood pellet boilers and low income households. Utilises multiple methodologies, } \\
\text { including a narrative literature review, statistical modelling, focus groups, case studies, and a household } \\
\text { survey. }\end{array}$ \\
\hline $\begin{array}{l}\text { [15] Wood Energy Solutions, } \\
2012\end{array}$ & Northern Ireland & $\begin{array}{l}\text { Grey literature, newsletter from a wood pellet boiler manufacturer that was involved with a wood pellet } \\
\text { boiler trial across social housing properties in Northern Ireland }\end{array}$ \\
\hline $\begin{array}{l}\text { [16] Wrapson and Devine- } \\
\text { Wright, } 2014\end{array}$ & England & $\begin{array}{l}\text { Semi-structured interviews with older person households that have low carbon and conventional } \\
\text { thermal technologies installed, to understand the factors that influence uptake, and how low carbon } \\
\text { heating is integrated within the home }\end{array}$ \\
\hline [17] Alakangas and Paju, 2002 & Finland & $\begin{array}{l}\text { Grey literature, a review of the wood pellet market, based on published literature, official market } \\
\text { statistics and case studies }\end{array}$ \\
\hline [18] Devine-Wright et al., 2014 & UK & $\begin{array}{l}\text { In-depth semi-structured interviews with older person private households and care home staff and } \\
\text { residents that use some form of low carbon thermal technology. Aims to understand the relationships } \\
\text { between older people, thermal comfort and low carbon technologies }\end{array}$ \\
\hline $\begin{array}{l}\text { [19] The Consumer Council, } \\
2014\end{array}$ & Northern Ireland & Grey literature, provides information on home heating oil prices \\
\hline [20] Trømborg et al., 2013 & $\begin{array}{l}\text { Finland, Germany, Norway, } \\
\text { Sweden and the US }\end{array}$ & Modelling of economic sustainability for wood pellet production plants, based on market statistics \\
\hline [21] Fiedler et al., 2006 & Sweden & Optimisation study of combined solar and pellet heating systems \\
\hline [22] Fiedler, 2004 & $\begin{array}{l}\text { Sweden, Austria and } \\
\text { Germany }\end{array}$ & $\begin{array}{l}\text { Policy and technology analysis of wood pellet heating in the three study countries, based on policy } \\
\text { documents and published literature }\end{array}$ \\
\hline [23] Ståhl and Wikström, 2009 & Sweden & $\begin{array}{l}\text { A literature review of academic and grey sources, including blog articles, to determine the problems } \\
\text { that householders experience using wood fuel pellets as a source of heat }\end{array}$ \\
\hline [24] Skjevrak and Sopha, 2012 & Norway & $\begin{array}{l}\text { A postal survey and regression analysis of early adopters of wood pellet heating to establish factors that } \\
\text { influence overall satisfaction }\end{array}$ \\
\hline $\begin{array}{l}\text { [25] Mahapatra and Gustavsson, } \\
2008\end{array}$ & Sweden & $\begin{array}{l}\text { Analysis of two household surveys to explore factors that influence householder's decision to adopt a } \\
\text { new heating system, including pellet boilers. }\end{array}$ \\
\hline [26] Carroll and Finnan, 2012 & Ireland & $\begin{array}{l}\text { Tested the physical and chemical properties of biomass pellets based on wood, willow, miscanthus, } \\
\text { wheat, barley and rape straws, }\end{array}$ \\
\hline [27] Limousy et al., 2013 & France & $\begin{array}{l}\text { Tested the physical and chemical properties of pellets produced from spent coffee grounds, and coffee } \\
\text { grounds pellets blended with pine sawdust }\end{array}$ \\
\hline $\begin{array}{l}\text { [28] European Pellet Council, } \\
2013\end{array}$ & Europe & Grey literature, handbook on the certification process for wood pellets for heating \\
\hline [29] Element Energy, 2008 & Great Britain & Economic modelling of the growth potential for microgeneration technology and a consumer survey \\
\hline [30] Roy et al., 2008 & UK & $\begin{array}{l}\text { Large survey of households who were considering or buying microgeneration heat technologies to } \\
\text { determine their experiences and motivations }\end{array}$ \\
\hline [31] Claudy et al., 2011 & Ireland & $\begin{array}{l}\text { Field survey of home owners to determine willingness to pay for microgeneration technologies and the } \\
\text { relative influence of subjective consumer perceptions }\end{array}$ \\
\hline $\begin{array}{l}\text { [32] Renewable Heat Incentive } \\
\text { Ltd, } 2014\end{array}$ & Great Britain & $\begin{array}{l}\text { Grey literature, provides information on the level of financial support provided by the government for } \\
\text { installing renewable heat technologies }\end{array}$ \\
\hline $\begin{array}{l}\text { [33] Department of Energy and } \\
\text { Climate Change, } 2014\end{array}$ & Great Britain & $\begin{array}{l}\text { Statistical data concerning the number of accredited installations of renewable heat systems through } \\
\text { two government funding schemes }\end{array}$ \\
\hline [34] Stelte, 2012 & Denmark & $\begin{array}{l}\text { Grey literature, guidelines that provide recommendations for the safe handling of wood pellets and } \\
\text { wood chips }\end{array}$ \\
\hline [35] Gauthier et al., 2012 & Germany and Switzerland & $\begin{array}{l}\text { Review of literature, two case studies and a series of experiments to measure CO production by wood } \\
\text { pellets to investigate lethal carbon monoxide poisoning in wood pellet storerooms }\end{array}$ \\
\hline [36] Melin, 2010 & Canada & $\begin{array}{l}\text { Grey literature, report from an industry association on off-gassing from wood pellets, with safety } \\
\text { recommendations }\end{array}$ \\
\hline [37] Bølling et al., 2009 & Global & Review of knowledge concerning the physicochemical properties of wood smoke particles \\
\hline [38] Olsson et al., 2003 & Sweden & $\begin{array}{l}\text { A series of experiments to investigate the chimney emissions and biofuel characteristics of domestic } \\
\text { softwood pellets }\end{array}$ \\
\hline [39] Cook et al., 2013 & Australia & Case study research to explore attachments to home and opposition to residential policy \\
\hline
\end{tabular}




\section{Findings}

\subsection{Advantages}

Across the literature, a number of key advantages of domestic wood pellet boilers have been identified, namely: environmental benefits, reduced heating costs and increased comfort, accessibility, and versatility. Each of these advantages will be discussed in turn, before moving on to the main barriers and risks associated with wood pellet heating.

\subsubsection{Environmental benefits}

There are key environmental benefits associated with wood pellet boilers. This is because if the biomass fuel is fully combusted, the amount of carbon dioxide produced is equal to the amount which was taken from the atmosphere during the growing stage, and so there is no net addition of $\mathrm{CO}_{2}$ [2]. Furthermore, wood fuel can be $\mathrm{CO}_{2}$ neutral if the rate of harvest equals the rate of re-growth [2]. One study has estimated that in 2008, 12.6 million tonnes of $\mathrm{CO}_{2}$ emissions were avoided in EU27 countries plus Norway and Switzerland, based on the substitution of coal and heating oil for 8.2 million tonnes of wood pellets [7]. Further environmental gains arise in contexts where wood pellets are produced locally as transport related emissions are reduced. Localised production of wood pellets has the added advantage of supporting local economies by providing new employment opportunities [3]. A survey of 669 adopters of wood pellet heating in Norway found that the main motivation for choosing wood pellet heating was that it is an environmentally friendly option [10], a finding that is reaffirmed by Lillema et al. [11]. Similarly, German research found that independence of fossil fuels is an important factor for deciding to adopt wood pellet heating [12].

\subsubsection{Reduced heating costs and increased comfort}

A key advantage of wood pellet heating is that it can significantly reduce domestic heating costs as pellets are usually cheaper than oil, particularly as wood fuels have higher energy content than heating oil. Indeed, comparative heating costs data from January 2014 shows that wood pellet heating is one of the cheapest methods of space and water heating for an average three bedroom house in the United Kingdom [13]. Wood pellet heating is consistently found to be cheaper than heating oil, liquefied petroleum gas and electric powered systems, as well as older natural gas fired systems [13]. Furthermore, as wood pellets are not subject to the same volatile global energy markets, prices are likely to remain relatively stable in the short term, although in some parts of the world (e.g. Northern Ireland) they can be both more volatile and more expensive than other sources of heating fuel [14]. For low-income households an additional benefit is that small $10 \mathrm{~kg}$ bags of pellets can be purchased at an affordable price in a 'pay as you go' manner, which can be particularly useful for weekly budgeting, as found in case studies from the installation of approximately forty biomass boilers in social housing properties across Northern Ireland [15].

Concern about high energy costs is likely to be a key driver for the uptake of wood pellet heating, indeed, a study of older households who live off-grid in England reported that the increasing price of oil, and the discourse of 'peak oil', was a trigger for households to investigate low carbon thermal technologies [16]. Similarly, Sopha et al. [10] found that the combination of low operation costs and an anticipated increase in electricity prices was an additional motivation for uptake of wood pellet heating in Norway. Similar processes occurred earlier in Finland, following a sharp increase in oil prices at the end of the 1990s [17].
As well as reducing heating costs, wood pellet heating systems can also increase comfort levels. Unlike solar thermal systems which are likely to operate intermittently, wood pellet systems can run continuously, and will continue to operate in sub-zero temperatures [15]. Wood pellet boilers are a natural replacement to oil fired systems as they are able to achieve operating temperatures of $80^{\circ} \mathrm{C}$ for water [15], which other renewable heating technologies may struggle to achieve. Furthermore, if wood pellet boilers are used in conjunction with underfloor heating, the system can achieve a comfortable, uniform thermal environment [18], which is beneficial for health and wellbeing.

\subsubsection{Accessibility}

In countries that lack a widespread natural gas network and are particularly rural, such as Northern Ireland where around $68 \%$ of households rely on oil for heating [19], wood pellet heating may be a good option as it does not depend on a fixed physical distribution network, as with natural gas. In addition, compared to other forms of wood biomass, pellets are suited for domestic use as they can be transported and stored easily because of the form and their size, and as they have a higher energy density [4,20,8]. An additional benefit of pellet boilers in terms of accessibility is that some models can fit through a standard house door, thus they can be installed in properties where access is a problem [15]. In addition, issues of theft, which are common with oil tanks, can be reduced with some pellet boiler models as the fuel can be stored in an integral hopper and locked [15].

\subsubsection{Versatility}

The final key advantage of wood pellet boilers is the versatility of the technology. For instance, wood pellet boilers can often be integrated relatively easily into existing properties with little or no change required to the existing radiator heating system [15]. Furthermore, they can be optimised in a number of ways, such as by using them in combination with a solar thermal system [21], or by using wood pellet boilers to heat multiple properties in a district heating set up, as is common in Sweden [6]. As SEAI [3] highlight, some boilers are available which offer a "dual fuel" burning option, for example wood logs and wood pellets, which may make the technology more desirable for consumers, and as will be highlighted later, in the future consumers may not be limited to just pellets composed of wood, but may be able to purchase pellets made from coffee grounds and fast growing sustainable crops such as wheat and barley straws.

\subsection{Issues and barriers}

However, for as many advantages which can be identified, nearly twice as many issues and barriers can be distinguished. Across the scientific and grey literature the main issues that emerged were: end-user problems, environmental risks, supply chain risks, high domestic equipment costs, storage, health risks, and conflict with existing home-making practices.

\subsubsection{End-user problems}

At the household level, a key issue for wood pellet boilers is they are labour-intensive for users, and in general will require more maintenance compared to conventional boilers, namely: refilling of pellets, cleaning the burner of ashes and slag, cleaning the flue gas passages, ash pan emptying, and cleaning the windows of stoves if used [22]. Whilst a half yearly or annual service is normally sufficient to prevent efficiency losses as a result of build-up of soot in oil and gas systems, wood fired boilers require more regular cleaning, sometimes weekly, to prevent efficiency losses $[3,23]$ as well as an increase in carbon monoxide 
levels as a result of reduced air supply [22]. Furthermore, if poor quality pellets are used or if the boiler is incorrectly adjusted causing imperfect combustion, higher amounts of ashes will be produced [23] which will increase cleaning and maintenance needs. For households accustomed to open fires, the maintenance is not too dissimilar to existing practices, and some higher specification burners are self-cleaning which eliminates all but the need for periodic ash removal from the ash pan [3], however, the manual handling of pellets is likely to be an inconvenience [23] and may be beyond some people's capabilities.

Additional end-user problems reported by respondents to a Norwegian study [24] included igniter failure, issues with the control system, noise, more work than expected, and complicated user guidance. Similarly, an earlier Swedish study reported unintentional shutdown of wood pellet heating systems was a problem [23], with issues of stoppages in the feeding system (meaning that no pellets are fed to the boiler), the feeding system running empty and backfiring. Excessive pellet fines, and pellets that are longer than standards allow were listed as the main causes for the feeding system to run empty or stop [23], whereas backfiring, which describes everything from the spreading of smoke into the boiler room, to a fire in the feeding system or fuel storage, is said to be mainly caused by insufficient chimney draught due to a bad chimney flue design or the accumulations of soot and ashes due to inadequate maintenance [23]. Whilst the introduction of quality standards for wood pellets across Europe in 2010 is likely to have alleviated many of the issues associated with excessive pellet fines and pellet length, wood pellet boilers are clearly complex systems that are susceptible to end-user problems, particularly if the boiler is not regularly maintained.

Whereas the innovators and early adopters of wood pellet heating were likely to have been very tolerant towards operational disturbances and were prepared to work hard to make their systems operate efficiently [23], similar levels of patience are unlikely to be found in a broader roll-out of wood pellet heating. There is very limited research that explores consumer awareness of wood pellet boilers, however, a Swedish study from 2008 found that compared to other heating systems, such as heat pumps, knowledge about pellet boilers was low, with around one-third of respondents stating they did not know even one aspect of pellet boilers [25]. Given the potentially low levels of consumer awareness and that the satisfaction of current users towards wood pellet heating will affect the willingness to recommend to others, it is important that adequate advice and support is provided to consumers and that high quality standards are upheld for the manufacture of pellets and boilers and at the point of installation to enable the diffusion of wood pellet heating technology.

\subsubsection{Environmental risks}

There are a number of environmental risks associated with the production, transportation and combustion of wood pellets. If wood is unsustainably extracted from environmentally sensitive areas, this can cause adverse environmental impacts, including degradation of watershed and catchment areas, and loss of biodiversity and habitat [2]. In terms of transport, if pellets are produced elsewhere and transported long distances by freight train, lorries, and/or cargo ship, the environmental impact of the transportation may negate some of the environmental gains, particularly as countries that are some distance away geographically, such as Russia, are among the main exporters of pellets [7].

The final element of environmental risk concerns emissions. As Fiedler [22] comprehensively argues, the method of combustion for domestic pellet burners is important for ensuring complete pellet combustion and subsequently low emissions and low slagging (sticking together of ash). There is an environmental trade off to be considered in the design of the pellet burner. For instance, too little air in the combustion chamber will result in increased emissions of carbon monoxide and unburnt hydrocarbons, but will keep the amount of nitrogen oxides in the flue gas small [22]. Whereas greater air levels will result in the release of more nitrogen oxides, but less carbon monoxide and unburnt hydrocarbons [22].

\subsubsection{Supply chain risks}

The key supply chains risks are the reliability of supply, in terms of cost and geographical coverage, and the quality of pellets supplied. Compared with other renewable technologies such as solar thermal which is perceived to provide 'free' energy [16], some households have expressed concern about being at the mercy of wood pellet manufacturers and suppliers with regard to pricing [16]. This is a legitimate observation, especially as wood pellets are not immune to sharp increases in price, particularly if the supply chain cannot respond to rising demand. For example, in early 2007 consumers in Austria and Germany were faced with exceptionally high pellet prices as a result of a cold winter the year before and a fast increase in Italian pellet demand [7]. Indeed, it has been estimated that the forestry in European Union countries can only supply around $45 \%$ of the predicted increased demand for pellets [7], necessitating imports from other countries, such as the USA, Canada and Russia, who are presently among the largest pellet producers [20]. This is not an ideal scenario in terms of energy security and potential supply chain faults.

An additional concern is that at present, dry residues from sawnwood production have been the main feedstock for wood pellet production; however, rising demand for pellets in conjunction with declining activity in the sawnwood industry means that future pellet production will to a larger extent be based on wet feedstock, such as wood chips, roundwood and wet sawdust [20]. This will result in close competition with wood-based industries, such as pulp and paper, and wood-based energy generation [20], which is likely to cause pellet prices to increase. Given the potential energy security and supply chain risks associated with increased European wood pellet demand, the viability of emerging alternative biomass pellets should be explored further to increase future diversity of supply. These include pellets made from willow and fast growing crops such as miscanthus, wheat and barley straws [26], as well as pellets made from waste food products such as spent coffee grounds [27]. Although pellets made from these materials are not yet achieving the same standards as traditional wood pellets, it is a promising market.

The supply of inferior quality pellets for domestic (and nondomestic) use is problematic as the chemical properties of pellets significantly influences the quality of the combustion, emissions and efficiency $[22,23]$. Consumers should be seeking to use pellets with low water content, for better heating value, and a low ash content to avoid slagging, whereby the ash sticks together in the passages of the burner. Given the importance of quality, a European certification system, the ENplus, has been operating since 2010 to ensure a consistent supply of high quality pellets that meet requirements for production, quality, labelling, logistics and storage [28]. The coverage of the ENplus scheme is growing, with ENplus certified companies across 23 countries, including the US and Canada, amounting to more than four million tonnes of ENplus certified pellets worldwide [9]. Consumers need to be educated on the importance of buying ENplus certified pellets, particularly as certified pellets should not cost significantly more than unregulated pellets as the associated costs for ENplus certification are estimated to be relatively low at around €0.10 per tonne [7]. 


\subsubsection{High domestic equipment costs}

As wood pellets cannot fuel existing fossil fuel burners, their use requires the installation of a new heating system, which has high associated capital costs [2]. For instance, in Ireland it is estimated that the typical costs range from $€ 5,000(£ 4,049)$ to $€ 15,000$ (£12,149) depending on the size of the house, heat demand, boiler type, boiler functionality and fuel store type [3], whilst in the UK, Element Energy [29] estimated that in 2008 an $11 \mathrm{~kW}$ biomass boiler would have cost $£ 10,801$ to install as a retrofit measure, but they predicted that this would reduce to $£ 8,594$ by 2020 . A related issue is the difficulties associated with retrofitting a house for a wood pellet boiler [10,30]. In a survey of over 900 UK households who were considering or buying renewable heat technologies, it was found that most people installing wood pellet heating needed to make unexpected modifications to their buildings and experienced more disruption than expected [30]. Karkania et al. [4] argue that high capital costs and risk perception may hamper the growth of the biomass heating market in Europe. Indeed, research from Norway found that high installation costs were a key barrier for 291 households that chose not to install wood pellet heating [10], and for lower income households, the capital cost will certainly be a barrier unless grants or low interest loans are available to cover all capital costs.

Work by Roy et al. [30] in 2008 found that the upper threshold that people would pay for wood-fuelled boiler systems (excluding radiators) was $£ 8,000$. By comparison, later research from Ireland on homeowners' willingness to pay (WTP) for microgeneration technologies [31] found that the median WTP for wood pellet boilers was $€ 3,476$ ( $\sim 2,826$ ), which is significantly below the market price for installing a wood pellet boiler. Their research further found that homeowners' WTP is not entirely based on rational cost-benefits evaluations, and is likely to be influenced by subjective perceptions of the technology, people's personal background and social environment [31]. These findings highlight the importance of educating consumers on the benefits of wood pellet boilers, as well as the importance of providing sufficient marked based instruments, such as subsidies or tax exemptions, to incentivise households to install pellet heating over established fossil fuel systems.

Important lessons can be drawn from countries that have already deployed market based instruments for wood pellet boilers. For instance, between August 2011 and March 2014, domestic customers in Great Britain installing biomass boilers were able to apply for a grant of $£ 950$ (pre-May 2013) or $£ 2,000$ (post-May 2013) towards the cost of installing the system through the Renewable Heat Premium Payment scheme [32]. However, by the end of the scheme in March 2014, biomass boilers accounted for just 15\% of all vouchers issued for renewable heat technologies, with 3,201 vouchers issued, compared to air source heat pumps which accounted for $38 \%$ of vouchers, and solar thermal, which accounted for a further $32 \%$ [33]. It may be that even with a grant of $£ 2,000$, wood pellet technology remains too expensive to purchase and install for many households, particularly in light of the earlier findings on willingness to pay, or is considered risky compared with air source heat pumps and solar thermal technology.

With regard to the influence of socioeconomic characteristics on the uptake of renewables, established research shows that certain consumer segments are more likely to adopt renewable energy or energy efficiency measures [31]. For instance middle-class homeowners who are not connected to a natural gas network tend to be early adopters [30], whilst older homeowners are less likely to install a new heating technology, especially if they do not expect to recoup their investment during their occupancy of the house [25]. Furthermore, Sopha et al. [10] found that significant differences existed between a group that adopted wood pellet heating, and the non-adopter group, with the adopter group dominated by middle- income households, who were relatively young compared with the non-adopter group.

\subsubsection{Storage}

Whilst the size and density of wood pellets makes them easier to transport and store than other forms of wood biomass, there are nevertheless a range of potential storage issues. For households, space for storing bulk purchases may be an issue, particularly as SEAI estimate that for a typical house to take advantage of bulk pellet purchasing they would need a minimum storage capacity of four tonnes, which is approximately $7-8 \mathrm{~m}^{3}$, whilst for bagged pellets, they suggest it would be sensible to have storage available for ten to twenty $15 \mathrm{~kg}$ bags [3]. Furthermore, the design of storage for wood pellets needs careful consideration to avoid the following issues: damp, self-heating and self-ignition, off-gas formation and oxygen depletion, and dust formation. In terms of damp, if pellets become damp and swell up, they are no longer usable [7], with potentially high spoilage costs. However, of greater concern is that a number of serious incidents have been reported across Europe in connection with incorrect handling of wood pellets, some of which have resulted in injury or even death [34]. Stelte argues that most people consider wood materials as harmless, natural products thus underestimating the risk potential [34]. One such risk is the selfheating and self-ignition of pellets, which can occur either by chemical oxidation reactions and/or microbiological decay [34], although this risk is associated with large storage silos rather than domestic storage scenarios. By comparison, off-gas formation and oxygen depletion is a serious risk for households; without adequate ventilation, poisonous carbon monoxide gases can build up, creating a reduction in oxygen levels which causes suffocation [35]. In certain conditions, the dispersed dust from wood pellets can combust [7], this is due to the flammable nature of wood dust which has a very large surface area compared to its mass [34].

\subsubsection{Health risks}

As already highlighted, a key health risk for users of wood pellets is that without adequate ventilation, a build-up of carbon monoxide and subsequent depletion of oxygen can occur in pellet storage areas; this has already caused several deaths in domestic homes across Europe [35,36]. The inhalation of pellet dust is also associated with health risks [23]. As Stelte [34] outlines, exposure to and inhalation of excessive quantities of dust particles can cause irritation of the lungs, nasal and respiratory system, as well as allergic reactions, and irritation of the eyes. Similarly, wood pellets can decay due to fungal infections, resulting in airborne fungal spores and toxins which can cause irritations and allergic reactions along the respiratory system [34]. The final key potential health risk concerns exposure to wood smoke particles [37,38], which is associated with a range of negative health effects, including increased morbidity and mortality from pulmonary and cardiovascular diseases [37]. However, the advanced technology and design of modern wood pellet boilers mean that emission of particulate matter is low in well maintained boilers; however, as discussed earlier, if a boiler is not correctly maintained, emissions will increase, compounding the risk of exposure to particulate matter.

\subsubsection{Conflict with existing home-making practices}

The final issue for wood pellet heating is that it is likely to conflict with existing home-making practices and daily routines and habits [31], in addition to introducing new practices. Research by Claudy et al. [31] found that wood pellet boilers were perceived as being difficult to operate, which may be considered a fair assessment given the maintenance associated with wood pellet 
boilers. Although, for households accustomed to open fires, the maintenance is not too dissimilar to existing practices, and some higher specification burners are self-cleaning which eliminates all but the need for periodic ash removal from the ash pan.

Wood pellet boilers may also come into conflict with existing home-making practices due to their lack of 'flame' effect, which is important for contributing to feelings of cosiness. Devine-Wright et al. [18] and Wrapson and Devine-Wright [16] have produced important findings on the value of cosiness and glow to older adults in the UK. They found that home-making practices may lead to the supplementing of renewable heating systems with stoves and fireplaces to provide comfort, cosiness and sociability [18], leading to many households in rural off-gas grid areas using a blend of several different technologies and fuels [16]. Wrapson and Devine-Wright [16] argue that such strong attachments to particular thermal comfort features and concepts of cosiness demonstrate how renewable heat technologies must not only replicate the satisfactory temperature levels of conventional heating systems, but also contribute to the cosiness of the home. These findings also demonstrate the importance of keeping in the mind the distinction between housing and the home. Whereas housing refers to the material structures and institutional components of the stock, home is a multidimensional concept that refers to the meanings and materials of everyday practices of dwelling [39], and decisions concerning the home are not always rational in energy efficiency or financial terms.

\section{Concluding discussion}

The purpose of this study was to assess the suitability and usability of wood pellet heating in domestic households. This synthesis of evidence has explored the main advantages, issues and barriers associated with domestic wood pellet boilers, as well as attitudes towards wood pellet heating, and the main drivers for consumers choosing renewable heat over established fossil fuel systems. The main advantages that have been identified for using wood pellet boilers in domestic settings include avoidance of significant levels of $\mathrm{CO}_{2}$ emissions compared with fossil fuel combustion, which has been an important driver for early uptake of wood pellet heating in Norway, a reduction in heating costs, increased comfort, ability to budget by buying small bags of pellets as required, and the versatility of the technology. However, it is clear that a number of potential risks exist at all stages of the supply chain, including environmental damage, inability to meet predicated future demand of pellets, potential price increases and supply of inferior quality pellets. In addition, the evidence indicates that wood pellet heating has a heavy reliance on perfection of design for optimal performance and safety, both in terms of pellets and boilers but also regarding the design of storage areas. Numerous end-user problems have been identified, such as unintentional system shut down, noise, excessive maintenance and difficulties handling the pellets; some of these end-user problems are likely to increase the maintenance costs of wood pellet heating compared with established heating systems, particularly if certain parts are prone to frequent replacement. This can significantly offset the savings that may be obtainable through pellets being cheaper than oil or other fuels at point of purchase.

The capital cost associated with wood pellet heating is found to be a key deterrent to uptake, as well as the need to make modifications to the property. Research demonstrates that the amount people are willing to pay for wood pellet heating is often significantly below the market price, perhaps due to perceived risk. This indicates a need to increase awareness of wood pellet heating as an option, as well as the need for market based instruments. The latter will be particularly important for low-income households in order to remove the capital costs barrier.
Existing social practices and expectations may also be a key constraint for the transition from established fossil fuel systems towards renewable thermal technologies such as wood pellet heating. It has been shown that considerable value is placed upon having a focal point of heat or cosy 'glow' for social interactions in the home, something which wood pellet boilers alone could not provide. Research has demonstrated there is no 'standard' domestic heating system in rural, off-gas grid households, with many households using a blend of several different technologies and fuels, which may be counterproductive to policy goals to reduce carbon emissions. In this context, it is important to distinguish between housing and the home, and to recognise that decision making by households is not always rational in energy efficiency terms.

Given the numerous potential risks and barriers that have been identified, it is evident that wood pellet boiler systems are not suited to every household, especially if the household members would struggle with heavy lifting and cleaning, or if the property lacks adequate space for the boiler and pellet storage. Compared with established fossil fuel systems, a wide range of considerations need to be borne in mind before any household opts for wood pellet heating, and in promoting the uptake of renewable heating technologies, national governments should ensure sufficient advice and information is available to households during the decision making process.

That said, in the right context, and with regular maintenance, wood pellet heating does show some early promise for use in domestic settings, and advances in technology are likely to improve the suitability and usability of wood pellet heating in domestic properties over time. Wood pellet heating also shows great potential for use in a district heating set up, especially as responsibility for maintenance and cleaning is removed from the individual. Wood pellet heating appears relatively well suited to regions that have a high dependency on oil, liquefied petroleum gas and electricity for heating as wood pellet heating is a cheaper and lower carbon option.

Based on the review of literature, a number of key recommendations have emerged:

- High quality and safety standards for domestic wood pellet boilers, their installation and professional maintenance are essential.

- Good quality wood pellets are vital for the optimal performance of wood pellet boilers. To this end, consumers should be encouraged to only purchase ENplus certified pellets.

- Marked based instruments such as full or partial subsidies and low-interest financing should be made available to remove financial barriers and increase uptake.

- Consumers need to be provided with adequate advice and support to increase knowledge of equipment management.

\section{Acknowledgements}

The authors are grateful for the financial support provided by Oak Foundation for the research leading to this review article. The authors would like to thank Bryson Energy, part of the Bryson Charitable Group, for their ongoing partnership on this project.

\section{References}

[1] Directive 2009/28/EC of the European Parliament and of the Council of 23 April 2009 on the promotion of the use of energy from renewable sources and amending and subsequently repealing Directives 2001/77/EC and 2003/30/EC

[2] Saidur R, Abdelaziz EA, Demirbas A, Hossain MS, Mekhilef S. A review on biomass as a fuel for boilers. Renew Sust Energ Rev 2011;15:2262-89. 
[3] SEAI. Best practice guide: wood burning technologies for irish consumers Dublin: Sustainable Energy Authority of Ireland; 2012.

[4] Karkania V, Fanara E, Zabaniotou A. Review of sustainable biomass pellets production - A study for agricultural residues pellets' market in Greece. Renew Sust Energ Rev 2012;16:1426-36.

[5] Liddell, C. (2011) Hard to treat homes in Northern Ireland: evaluation report. Northern Ireland Electricity and the Department for Social Development.

[6] Olsson O, Hillring B, Vinterbäck J. European wood pellet market integration - A study of the residential sector. Biomass Bioenerg 2011;35:153-60.

[7] Sikkema R, Steiner M, Junginger M, Hiegl W, Hansen M, Faaij A T. The European wood pellet markets: current status and prospects for 2020. Biofuels, Bioproducts Biorefining 2011;5(3):250-78.

[8] Mola-Yudego B, Selkimäki M, González-Olabarria JR. Spatial analysis of the wood pellet production for energy in Europe. Renew Energ 2014;63:76-83.

[9] AEBIOM. European bioenergy outlook. Brussels: European Biomass Association; 2013; 2013.

[10] Sopha BM, Klöckner CA, Hertwich EG. Adopters and non-adopters of wood pellet heating in Norwegian households. Biomass Bioenerg 2011;35:652-62.

[11] Lillemo SC, Alfnes F, Halvorsen B, Wik M. Households' heating investments: The effect of motives and attitudes on choice of equipment. Biomass Bioenergy 2013;57:4-12.

[12] Michelsen CC, Madlener R. Homeowners' preferences for adopting innovative residential heating systems: a discrete choice analysis for Germany. Energ Econ 2012;34:1271-83.

[13] Sutherland tables (2014) Comparative heating costs - Northern Ireland January 2014. 〈http://www.sutherlandtables.co.uk/>; 2014 [accessed 17.06.14].

[14] Gray B, Thomson H, Liddell C. Low income households \& wood pellet boilers in Northern Ireland: a feasibility study. Coleraine: University of Ulster; 2014.

[15] Wood Energy Solutions. Go pellets spring newsletter. 〈http://www.woodener gysolutions.co.uk/brochures/Newsletter_Go_Pellets_Spring_2012.pdf); 2012 [accessed 07.05.14].

[16] Wrapson W, Devine-Wright P. 'Domesticating' low carbon thermal technologies: diversity, multiplicity and variability in older person, off grid households. Energy Policy 2014;67:807-17.

[17] Alakangas, E, Paju, P. Wood pellets in Finland - technology, economy and market: OPET Report 5. Jyväskylä: VTT Processes. 〈http://www.ateap.cz/new Pelety Finsko.pdf); 2002. [accessed 22.05.14].

[18] Devine-Wright P, Wrapson W, Henshaw V, Guy S. Low carbon heating and older adults: comfort, cosiness and glow. Build Res Inf 2014;42(3):288-99.

[19] The Consumer Council. (2014) Home heating oil. 〈http://www.consumercoun cil.org.uk/energy/home-heating-oil/ $>$; 2014 [accessed 16th05.14].

[20] Trømborg E, Ranta T, Schweinle J, Solberg B, Skjevrak G, Tiffany DC. Economic sustainability for wood pellets production - A comparative study between Finland, Germany, Norway, Sweden and the US. Biomass Bioenergy 2013;57:68-77.

[21] Fiedler, F, Bales, C, Persson, T, Thür, A. (2006) Design method for solar heating systems in combination with pellet boilers/stoves, Paper presented at EuroSun conference, Glasgow, 26th-29th June.

[22] Fiedler F. The state of the art of small-scale pellet-based heating systems and relevant regulations in Sweden, Austria and Germany. Renew Sust Energ Rev 2004;8:201-21.
[23] Ståhl M, Wikström F. Swedish perspective on wood fuel pellets for household heating: a modified standard for pellets could reduce end-user problems. Biomass Bioenergy 2009;33:803-9.

[24] Skjevrak G, Sopha BM. Wood-pellet heating in Norway: early adopters' satisfaction and problems that have been experienced. Sustainability 2012;4:1089-103.

[25] Mahapatra K, Gustavsson L. Innovative approaches to domestic heating: homeowners' perceptions and factors influencing their choice of heating system. Int J Consum Stud 2008;32:75-87.

[26] Carroll JP, Finnan J. Physical and chemical properties of pellets from energy crops and cereal straws. Biosyst Eng 2012;112(2):151-9.

[27] Limousy L, Jeguirim M, Dutournié P, Kraiem N, Lajili M, Said R. Gaseous products and particulate matter emissions of biomass residential boiler fired with spent coffee grounds pellets. Fuel 2013;107:323-9.

[28] European Pellet Council. Handbook for the certification of wood pellets for heating purposes Version 2.0. Brussels: European Pellet Council. 〈http://www. enplus-pellets.eu/wp-content/uploads/2012/01/ENplus-Handbook-2.0.pdf ; 2013 [accessed 16th.05.14].

[29] Element Energy.. The growth potential for Microgeneration in England, Wales and Scotland: final appendix. Cambridge: Element Energy Limited; 2008.

[30] Roy R, Caird S, Abelman J. YIMBY generation - yes in my back yard! UK householders pioneering microgeneration heat. London: The Energy Saving Trust; 2008.

[31] Claudy MC, Michelsen C, O'Driscoll A. The diffusion of microgeneration technologies - assessing the influence of perceived product characteristics on homeowners' willingness to pay. Energy Policy 2011;39:1459-69.

[32] Renewable Heat Incentive Ltd. The 'Renewable Heat Premium Payment'. 〈http:// www.rhincentive.co.uk/RHI/regulation/premium/>; 2014 [accessed 30 ${ }^{\text {th }} .06 .14$ ] .

[33] Department of Energy and Climate Change. Non-domestic RHI, RHPP and domestic RHI deployment monthly data: May 2014. 〈https://www.gov.uk/ government/publications/rhi-and-rhpp-deployment-data-may-2014); 2014 [accessed 30.06.14].

[34] Stelte W. Guideline: storage and handling of wood pellets. Taastrup: Danish Technological Institute; 2012.

[35] Gauthier S, Grass H, Lory M, Krämer T, Thali M, Bartsch C. Lethal Carbon Monoxide Poisoning in Wood Pellet Storerooms-Two Cases and a Review of the Literature. Ann Occup Hyg 2012;56(7):755-63.

[36] Melin, S. Review of off-gassing from wood pellets: a Canadian perspective. 〈http:// www.pellet.org/images/2010-02-26_Review_of_Off-gassing_from_Wood_Pellets. pdf ; 2010 [accessed 28.04.14]

[37] Bølling AK, Pagels J, Yttri KE, Barregard L, Sallsten G, Schwarze PE, et al. Health effects of residential wood smoke particles: the importance of combustion conditions and physicochemical particle properties. Part Fibre Toxicol 2009;6:29.

[38] Olsson M, Kjällstrand J, Petersson G. Specific chimney emissions and biofuel characteristics of softwood pellets for residential heating in Sweden. Biomass Bioenerg 2003;24:51-7.

[39] Cook N, Taylor E, Hurley J. At home with strategic planning: reconciling resident attachments to home with policies of residential densification. Aust Planner 2013;50:130-7. 